\begin{tabular}{|l|l|}
\hline $\begin{array}{l}\text { 2. To: (Receiving Organization) } \\
\text { Distribution }\end{array}$ & $\begin{array}{l}\text { 3. From: (Originating Organization) } \\
\text { Engineering Testing } \\
\text { Laboratory - } 8 \mathrm{C} 921\end{array}$ \\
\hline $\begin{array}{l}\text { 5. Proj./Prog./Dept./Div.: } \\
106847 / \text { AA30 }\end{array}$ & $\begin{array}{l}\text { 6. Design Authority/ Design Agent/Cog. } \\
\text { Engr.: } \\
\text { Cog Engineer: Graham Maclean }\end{array}$ \\
\hline
\end{tabular}

8. Originator Remarks:

For review and release

11. Receiver Remarks: 11A. Design Baseline Document? [] Yes [X] No

\begin{tabular}{|l|} 
4. Related EDT No.: \\
$N / A$ \\
7. Purchase Order No.: \\
$N / A$
\end{tabular}

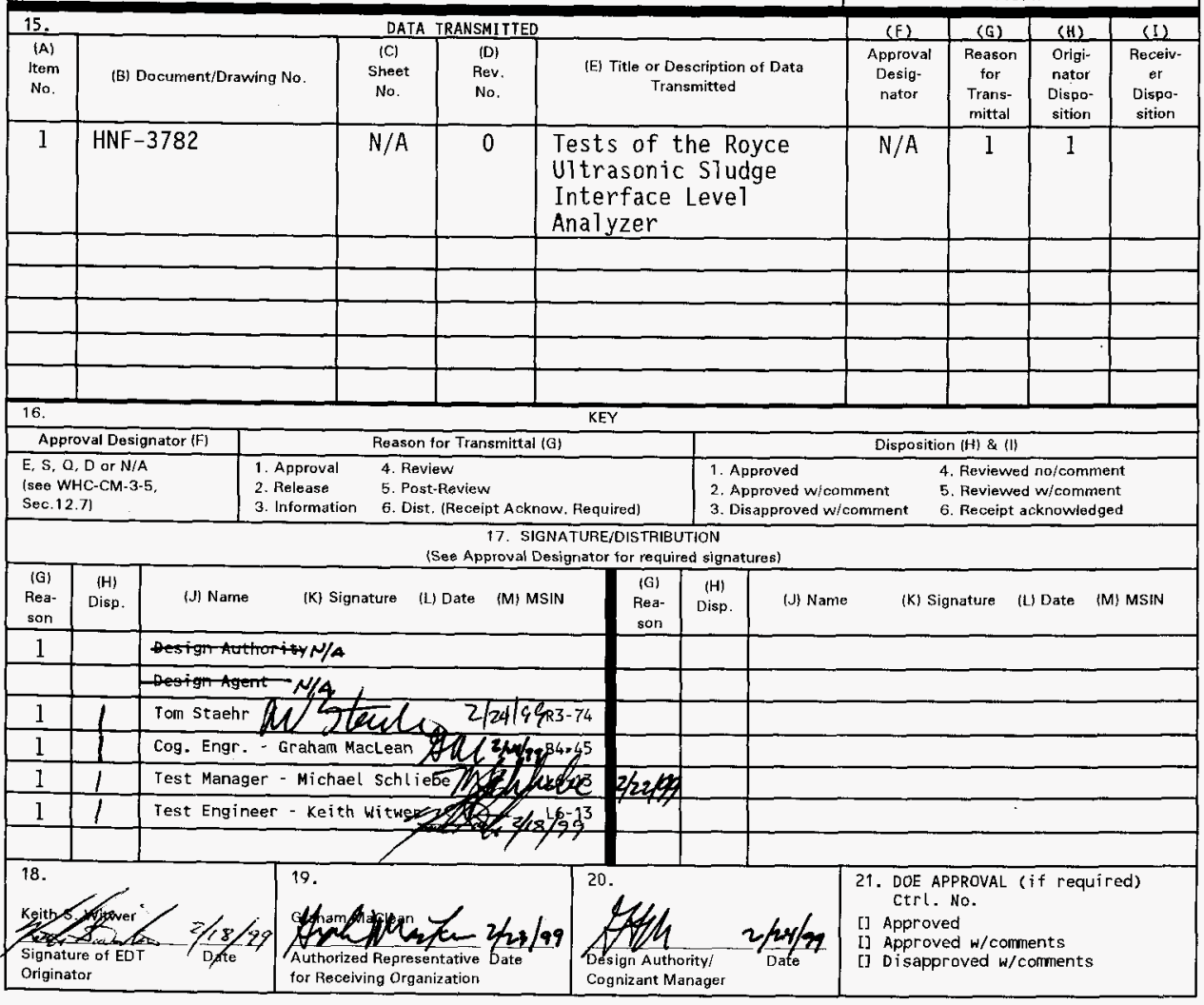




\section{Tests of the Royce Ultrasonic Sludge Interface Level Analyzer}

Keith S. Witwer

Numatec Hanford Corporation, Richland, WA 99352

U.S. Department of Energy Contract DE-ACO6-96RL13200

$\begin{array}{ll}\text { EDT/ECN: } 618466 & \text { UC: } 2030 \\ \text { Org Code: } 8 C 921 & \text { Charge Code: } 106847 / \text { AA30 } \\ \text { B\&R Code: Ew 3130010 } & \text { Total Pages: } 36\end{array}$

Key Words: Ultrasonic, Interface, Royce, ETL, Gamma

Abstract: This document describes testing carried out in 1995 on the Royce Interface Level Analyzer. The testing was carried out in the 305 Bldg., Engineering Testing Laboratory, 300 Area. The Level Analyzer was shown to be able to effectively locate the solid liquid interface layer of two different simulants under various conditions and was able to do so after being irradiated with over 5 million RADS gamma from a Cobalt 60 source.

IRADEMARK DISCLAIMER. Reference herein to any specific comercial product, process, or service by trade name, trademark, manufacturer, or otherwise, does not necessarily constitute or imply its endorsement, recommendation, or favoring by the United States Government or any agency thereof or its contractors or subcontractors.

Printed in the United States of America. To obtain copies of this document, contact: Document Control Services, P.0. Box 950, Mailstop H6-08, Richland WA 99352, Phone (509) 372-2420; Fax (509) 376-4989.
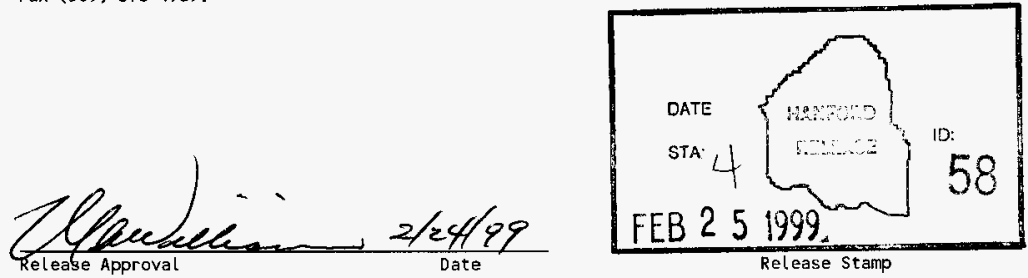

Approved for Public Release 
HNF -3782

ReV. 0

PAGE 2

TESTS OF THE ROYCE ULTRASONIC SLUDGE INTERFACE LEVEL ANALYZER

HNF-3782, REV 0

January 1999

Keith S. Witwer

Engineering Testing Laboratory

Numatec Hanford Company

Richland. Washington 


\section{TABLE OF CONTENTS}

1.0 INTRODUCTION . . . . . . . . . . . . . . . . . . . . . . . . . 4

2.0 TEST OBJECTIVES . . . . . . . . . . . . . . . . . . . 4

3.0 TEST EQUIPMENT . . . . . . . . . . . . . . . . . . . 5

3.1 ULTRASONIC INTERFACE LEVEL ANALYZER . . . . . . . . . . . . 5

3.1.1 SENSOR UNIT . . . . . . . . . . . . . . . . . 5

3.1 .2 ANALYZER UNIT . . . . . . . . . . . . . . . . 5

3.2 DATA ACQUISITION SYSTEM . . . . . . . . . . . . . . . . 6

3.3 TEST SIMULANTS . . . . . . . . . . . . . . . . . . 6

3.3.1 WATER . . . . . . . . . . . . 6

3.3 .2 LIME SLURRY . . . . . . . . . . . . . . . 6

3.3.3 IRON HYDROXIDE SLURRY . . . . . . . . . . . . . 6

4.0 TEST DESCRIPTION . . . . . . . . . . . . . . . . . . . . . 7

4.1 BASELINE PERFORMANCE TESTS . . . . . . . . . . . . . . . . 7

4.2 GAMMA IRRADIATION . . . . . . . . . . . . . . . . . . . . . 7

4.3 LIME SLURRY TESTS . . . . . . . . . . . . . . . . . . . . . . . . . 8

4.4 IRON HYDROXIDE SLURRY TESTS . . . . . . . . . . . . . . . . 8

5.0 TEST RESULTS . . . . . . . . . . . . . . . . . . . . . . . . . 9

5.1 GAMMA IRRADIATION . . . . . . . . . . . . . . . . . . . 9

5.2 LIME SLURRY TESTS . . . . . . . . . . . . . . . . . . . . . . . . 9

5.3 IRON HYDROXIDE SLURRY TESTS . . . . . . . . . . . . . . 10

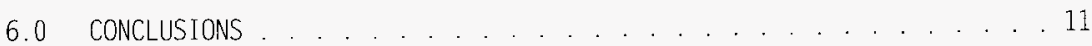

APPENDIX A - GAMMA IRRADIATION AND LIME SLURRY PROFILE GRAPHS . . . . . . . 12

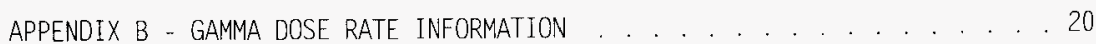

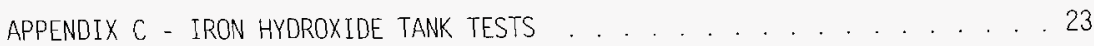


HNF -3782

Rev. 0

PAGE 4

\section{TESTS OF THE ROYCE ULTRASONIC SLUDGE INTERFACE LEVEL ANALYZER}

\subsection{INTRODUCTION}

This report summarizes the results of testing done on a Royce Model 2511 U1trasonic interface Level Analyzer at the 305 Building. Engineering Testing Laboratory (ETL), in 1995. The testing was done to demonstrate the performance of the level analyzer in a liquid/sludge simulant under various operating conditions. The information in this report was originally presented by the author in two Westinghouse Hanford Company (WHC) internal memos to Mr. Graham Maclean: dated May 3rd and September 19, 1995. More detailed descriptions about the tests run as well as some technical details about the Level Analyzer not presented in the earlier memos are included in this report.

\subsection{TEST OBJECTIVES}

The test objectives can be broken down into two groups. The first group reflects the testing done between January and May, 1995 and the second set of objectives reflect the testing done in September. 1995.

Early 1995 Objectives:

A) Test the Royce Model 2511 in a clear water environment to identify baseline performance capability.

B) Test the Royce Model 2511 in a 5000 gallon tank of lime solution to show its ability to distinguish solid/liquid interface layers.

B) Test the effects of radiation exposure on the sensor body by exposing it to $5 \times 10^{6}$ RAD gamma radiation. Measure any sensor degradation periodically during the exposure period as well as after exposure in the clear water and lime test tanks.

Late 1995 Objectives:

C) Verify the usefulness of the Royce Mode 2511 by testing it in a five foot diameter, 16 foot tal1 steel tank containing a ferric hydroxide simulant. Test the instrument to see if it can identify the sludge layering of the simulant in various stages of settring. 
HNF -3782

Rev. 0

PAGE 5

\subsection{TEST EQUIPMENT}

\subsection{ULTRASONIC INTERFACE LEVEL ANALYZER}

The Royce Instrument Corporation Model 2511 Interface Level Analyzer system used for this testing was composed of two main components:

1) Analyzer/Transceiver - Mode1 2511

2) Sensor - Model 25MRA

The system uses an ultrasonic ranging technique (SONAR) to measure the depth of blanket interfaces within a holding tank. A small sensor mounted on the end of a 3/4" diameter pipe is placed just under the surface of a liquid/simulant. An ultrasonic signal is sent and received through the sensor and forwarded by coaxial cable to the analyzer unit. The analyzer unit processes the information and provides a visual readout of the sludge/liquid interface layer(s) and/or tank bottom position. Specifics of the operation of the components are given below.

\subsubsection{SENSOR UNIT}

The sensor unit. Model 25MRA, is a 2" diameter by 3" long probe with a 1/4" thick outer she11 made of a carbon fiber/epoxy composite material. A crystal inside the sensor body acts as both a transmitter and receiver or "transceiver". Short $212 \mathrm{kHz}$ bursts of ultrasonic energy transmitted from the crystal travel in a narrow beam towards the tank bottom. The transmitted signal reflects off any interface layers and/or tank bottom and the echoes are received back into the crystal.

The outer carbon fiber/epoxy shell of the sensor is designed to withstand extreme environmental conditions such as high temperatures and very corrosive materials.

\subsubsection{ANALYZER UNIT}

The analyzer unit. Mode 72511 , measures the time delay and magnitude of the returning signals and stores this information in its memory in the form of a tank profile. The procedure is repeated several times to filter anomalous returns until an average "clean" profile is developed. The analyzer will adjust the power level of the transmitted signal based on the strength of returned signals. Severai factors will influence the strength of the returned signal such as density of the media being measured and distance to interface layer or tank bottom. The analyzer will attempt to adjust the power output to provide a signal return that will be easily distinguishable from background 
HNF -3782

ReV. 0

PAGE 6

noise. Once the profile is stored in memory, the analyzer can determine the depth of the interface, the depth of the tank bottom, and the depth of any "fluff" layers suspended above the interface. This information is then displayed both numerically and graphically on the front panel readout, or sent to a remote data acquisition system where the same information can be displayed. manipulated and/or permanentiy stored using vendor supplied software.

\subsection{DATA ACQUISITION SYSTEM}

For this testing. a microcomputer was connected to the analyzer assembly via an RS232 serial interface. Data from the analyzer was then viewed using software provided by the vendor. This software enabled the user to view and record the data from the analyzer to disk as standard ASCII text data. The data could then be manipulated using third party software such as a spreadsheet for example.

\subsection{TEST SIMULANTS}

\subsubsection{WATER}

Initial equipment assembly and operational checks were done in a thirtythousand-gallon test pool located in the 305 Building. ETL. This clean water test pool provided a convenient location to "fine calibrate" the system and evaluate its operational characteristics.

\subsubsection{LIME SLURRY}

A twelve foot diameter, six foot ta11, 5000 gallon tank containing a saturated Lime slurry, located in the ETL, provided a convenient media to further evaluate the performance of the system. A recirculating pump provided mixing of the solution when needed. A sludge/liquid interface in the solution was readily apparent and typically settled out from a fully mixed condition to about three feet below the surface in 24 hours.

\subsubsection{IRON HYDROXIDE SLURRY}

A sixteen foot tal1, five foot diameter steel tank containing a 2.8 wt \% ferric hydroxide slurry in a 7.0 wt \% sodium nitrate and 1.4 wt. \% sodium hydroxide solution was used for the final evaluation of the system. The slurry was made by adding sodium hydroxide to a ferric nitrate solution. precipitating ferric hydroxide. A recirculating pump attached to the tank as 
HNF -3782

Rev. 0

PAGE 7

wel1 as a hand-held air sparger provided mixing of the tank contents when needed.

\subsection{TEST DESCRIPTION}

\subsection{BASELINE PERFORMANCE TESTS}

As mentioned previously, the sensor was placed in a 15 feet deep. 30,000 gailon pool of water to perform initial equipment checkout and calibration. The depth of the pool as indicated by the level analyzer was compared against the previously known depth of the pool (that had been measured by mechanical means). Fine calibration adjustments were made to the level analyzer to bring it into agreement with the known depth of the pool to an accuracy of $+/=0.1$ feet.

\subsection{GAMMA IRRADIATION}

The customer desired that the level analyzer withstand an operational radiation dose of 250 RAD per hour for a duration of two years, or five million RAD total. The manufacturer, (Royce), had no experience or data on the system being used in a radioactive environment. Therefore, evaluation of the system during and after exposure to a radioactive source needed to be done before it could be considered a viable system for on-site use. A nearby facility, the 3730 Building Gamma Pit, had a Cobalt $60\left({ }^{60} \mathrm{Co}\right)$ source that could provide gamma irradiation. The specified exposure of five million RAD was carried out over a four day period. This four day duration was dictated by physical limitations in the Gamma Facility as well as the desire to monitor the Level Analyzer during irradiation. Actual applied dosage was .658E+05 $\mathrm{RAD} / \mathrm{hr}$ for seventy-six hours.

The data acquisition system previously used with the water and Lime tank tests was setup in the Gamma Facility to monitor and record data from the Analyzer during irradiation. A constant amplitude target echo was needed while in the Gamma pit to provide a real time indication of any sensor degradation. This was accomplished by surrounding the sensor with a three and one-half inch diameter. two foot long stainless steel tube - closed at one end. With the tube filled with water, a signal from the sensor would travel to the bottom of the tube, reflect back and provide a constant interface level signal for the analyzer unit. The attenuation from the stainless steel tube and the water was accounted for when calculating the applied dose rate. 
HNF -3782

Rev. 0

PAGE 8

\subsection{LIME SLURRY TESTS}

The sensor was placed in the five thousand gallon lime tank both prior to and after being irradiated at the Gamma Facility. In both cases the lime slurry was first thoroughly mixed with a recirculating pump and then the analyzer was tested to see if it could "see" the tank bottom. The solids in the slurry were allowed to settle until a distinct interface layer was developed. The system was then tested to see if the interface layer as well as the bottom of the tank could be seen. The interface layer could be seen through the semi-transparent tank wall when a light was shined nearby. A measuring tape was used to verify the exact position of the interface layer.

An additional test of the system was run in the lime tank containing the lime slurry - after irradiation. A three foot by three foot square frame was made with thin $(3 \mathrm{mi} 1)$ plastic wrap stretched over it. This was placed three feet down below the sensor in a fully mixed tank to see how well the sensor could detect: 1) The position of the plastic interface and 2) The position of the bottom of the tank through the plastic interface. This test was of a scoping nature and was intended only to demonstrate the sensor's capability to see through a density interface layer. Three mil plastic was used because it was readily available.

\subsection{IRON HYDROXIDE SLURRY TESTS}

The first series of tests involved placing the sensor in the unmixed tank with a distinct liquid/sludge interface layer about six and one half feet below the surface. (Verification of the position of the interface layer was made by shining an underwater light on measuring stick placed into the slurry and observing the distance to the surface.) The mixer pump was run. injecting clear supernate (liquid above the interface layer) into the lower sludge layer. This allowed the interface layer to rise and still remain intact so that the analyzer could track its upward motion. Like the lime slurry tests. the analyzer was tested to see how well it could measure the position of the interface layer as well as the position of the tank bottom. It was then tested in a fully mixed tank to see how well it could measure the position the tank bottom.

The second series of tests were run to determine the maximum height that the probe could be placed and still be able to see the tank bottom in a fully mixed tank. This involved furly mixing the tank contents and keeping it mixed with the mixing pump. The sensor was then incrementally lowered from a position just below the surface downwards until the tank bottom position could be clearly seen.

The third series of tests involved determining how close the sensor could be placed next to a vertically oriented steel pipe and still obtain 
HNF -3782

Rev. 0

PAGE 9

usable information. This was of interest because of the possibility of locating the sensor in a waste tank with other metal objects, a tank riser, or a tank wall nearby. A twenty foot long. six inch diameter steel pipe was placed in the five foot diameter tank with one end resting on the bottom. With the sludge/liquid layer at about six feet below the surface, the sensor was progressively moved closer to the edge of the pipe until a clean interface layer profile was lost.

The fourth series of tests involved measuring the rate of settling of the sludge interface layer without the mixer pump running. This was done simply by keeping the sensor stationary and recording the interface profile at various times for several days.

\subsection{TEST RESULTS}

Note that when reading the graphs relating to the test results, the vendor software automatical7y injects the words "THE INTERFACE LAYER IS XX FEET FROM THE TOP OF THE TANK". This should be understood as "Xx feet below the face of the sensor" for these tests. In many process applications, the position of a interface layer relative to the surface level, or TOP OF THE TANK. is desired. The sensor can be placed anywhere below the surface layer as long as this "offset depth" below the surface is programmed into the system.

\subsection{GAMMA IRRADIATION}

Appendix A shows graphs of the analyzer echo profiles in the gamma pit during stages of gamma irradiation. Notice that there is no measurable degradation in the sensor performance before, during or after irradiation. The sensor body was also inspected for any physical changes after irradiation and none were found. Appendix $B$ gives dose rate information relating to the positioning of the sensor in the Gamma Facility.

\subsection{LIME SLURRY TESTS}

No difference in the response of the sensor was detected between tests run before and after irradiation. The system was able to accurately detect the interface layer, the bottom of the tank and the location of a plastic sheet placed within the lime solution. Graphs of the lime interface profiles are also shown in Appendix A. 
HNF-3782

Rev. 0

PAGE 10

\subsection{IRON HYDROXIDE SLURRY TESTS}

The graphical information for these tests is given in Appendix $C$.

The first series of tests, which involved placing the sensor in the unmixed tank with a distinct liquid/sludge interface layer about six and one half feet below the surface. are shown in graphs 1 through 5 . These show a clear picture of the interface layer slowly rising to the surface from a starting depth of 6.5 feet in approximately one hour. Sensor gain varied from 2 to 14 during these tests. Note that between six to ten minutes after the pump was started the ability to see the bottom of the tank was lost.

Graphs 6 through 11 show the second series of tests which were run to determine the maximum height that the probe could be placed and still be able to see the tank bottom in a fully mixed tank. As can be seen, in the fully mixed tank, both while the mixer pump is running and shortly thereafter. the maximum readable depth is about 8 feet. It should be noted however that once this dynamic condition has subsided, the ability to detect the bottom through the dense sludge improves dramatical7y. Graph number 12 shows the probe detecting the bottom quite clearly after much of the movement has subsided (65 hours after pump shutoff).

The third series of tests are shown in graphs 13 through 17 . These show how close the sensor could be placed next to a vertically oriented steel pipe and still obtain usable information. Graph 13 shows the sensor placed approximately 12 inches away from the pipe. The depth of the interface layer is 5.8 feet below the sensor and the tank bottom is approximately 14 feet below the sensor. The sensor is incrementally moved closer to the steel pipe. a few inches at a time, but with no change in depth. The remaining graphs show the progression from distant to near as the signal clarity finaliy degrades to an unusable level as the sensor is moved closer than six inches (measured from center axis of sensor to outside edge of pipe).

The fourth and final series of tests involved measuring the rate of settling after the mixer pump was shutoff. Graphs 18 through 23 show the sludge interface level at different times after pump shutoff.

A curve fit algorithm called a "one-phase exponential association" can be used to fit the data points fairly we 17 . This algorithm minimizes the sum of the squares of the actual distance of points from the curve. Convergence was reached when two consecutive iterations changed the sum-of-squares by less than $0.01 \%$. The formula is in the form of:

$$
\begin{aligned}
& Y=\operatorname{Mmax}^{*}\left(1-\exp \left(-K^{*} X\right)\right. \\
& \text { Where } \begin{aligned}
Y & =\text { Interface Layer Depth in Feet below surface } \\
Y \max & =4.815 \text { (Iterated best fit value) } \\
X & =\text { Elapsed Hours after Pump is shut off }
\end{aligned}
\end{aligned}
$$


Giving:

$$
k=0.05232 \text { (Iterated rate constant) }
$$

Interface Layer $=4.815 *(1-\exp (-0.05232 *$ Hours after pump shutoff $)$

Note that this curve fit formula is based on only six data points and therefore does not precisely reflect the settling action of the simulant. Were additional data points recorded, a more precise curve fit would have been determined. A graph of the data points and the curve fit is shown in Appendix c. Graph 24.

\subsection{CONCLUSIONS}

These tests show the ability of the ROYCE Interface Sludge Level Analyzer to measure the location of a sludge/liquid interface layer in two different simulants. The analyzer showed no measurable degradation after exposure to five miliion RAD of gamma radiation. It performed as advertised by the manufacturer and revealed no identifiable defects. 
APPENDIX A - GAMMA IRRADIATION AND LIME SLURRY PROFILE GRAPHS

Figure 1 - Image of bottom of water filled SS Steel Tube immediately after installation into Gamma Pit

Figure 2 - Image of tube approximately mid-way through irradiation

Figure 3 - Image of tube just before removal from Gamma Pit

Figure 4 - Image of supernate/lime sludge interface and tank bottom interface in unmixed Time tank

Figure 5 - Image of partially mixed tank with supernate/lime sludge interface just over a foot away from sensor

Figure 6 - Image of completely mixed lime tank showing tank bottom interface

Figure 7 - Image of fully mixed tank with an artificial plastic interface and tank bottom interface 


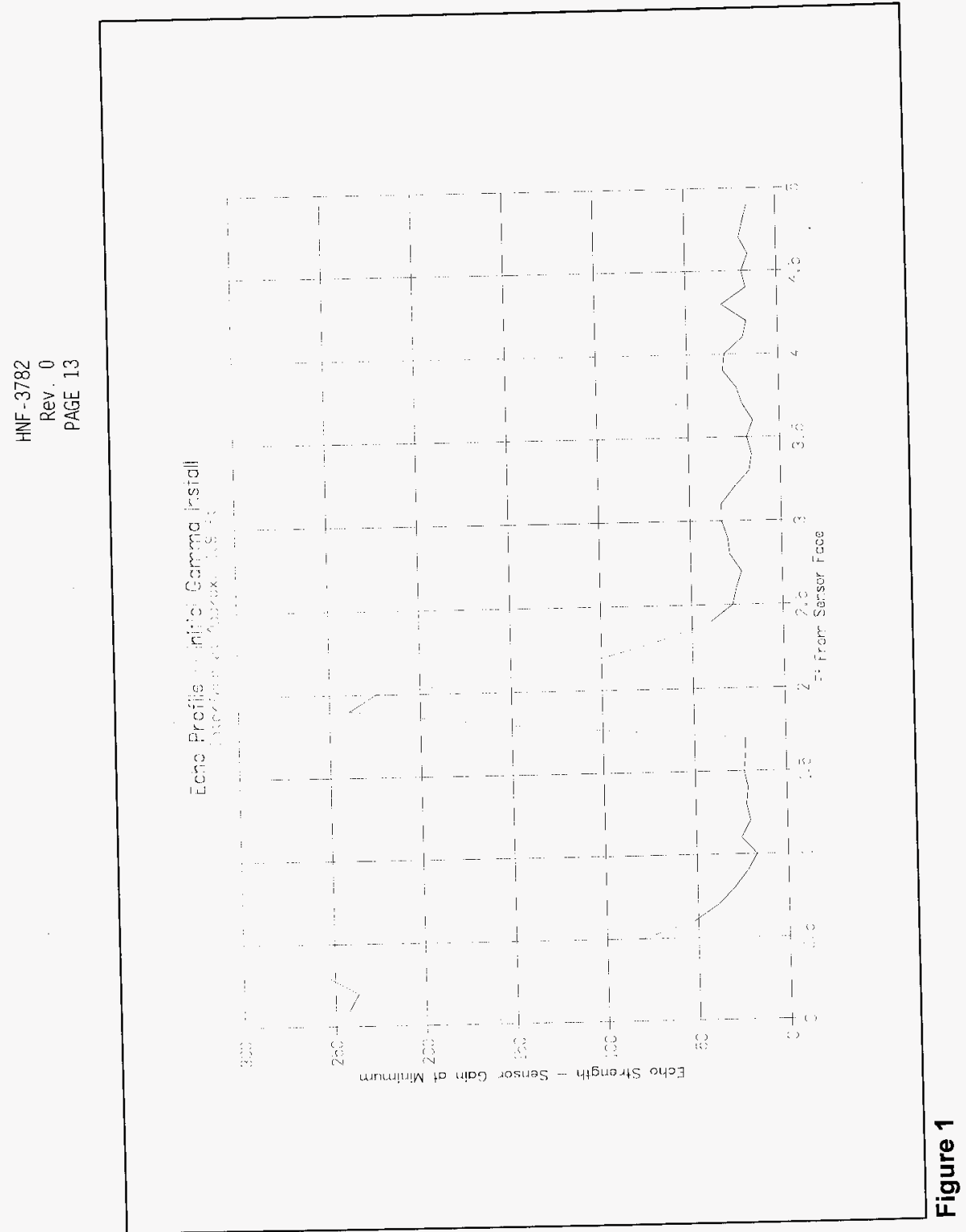




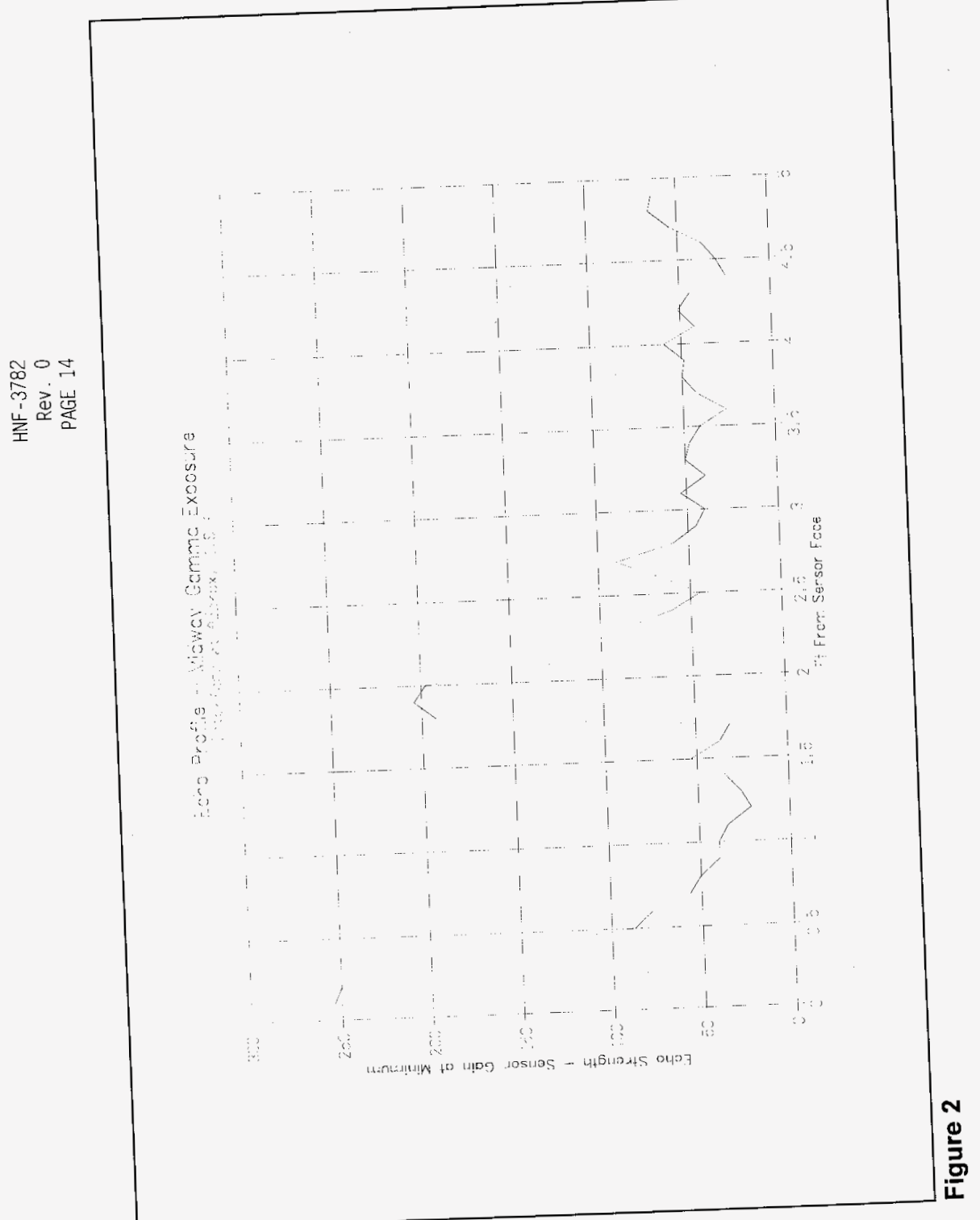




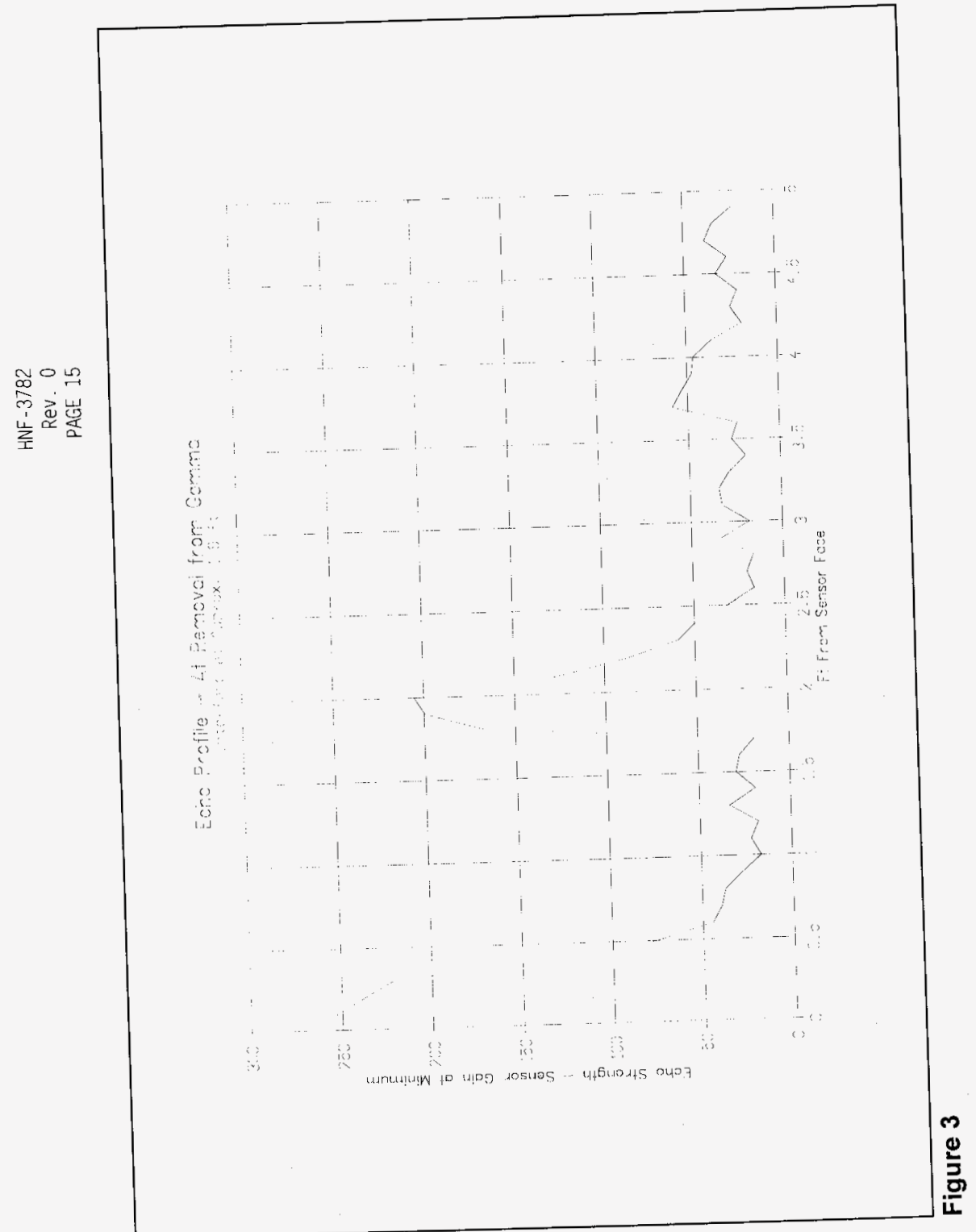




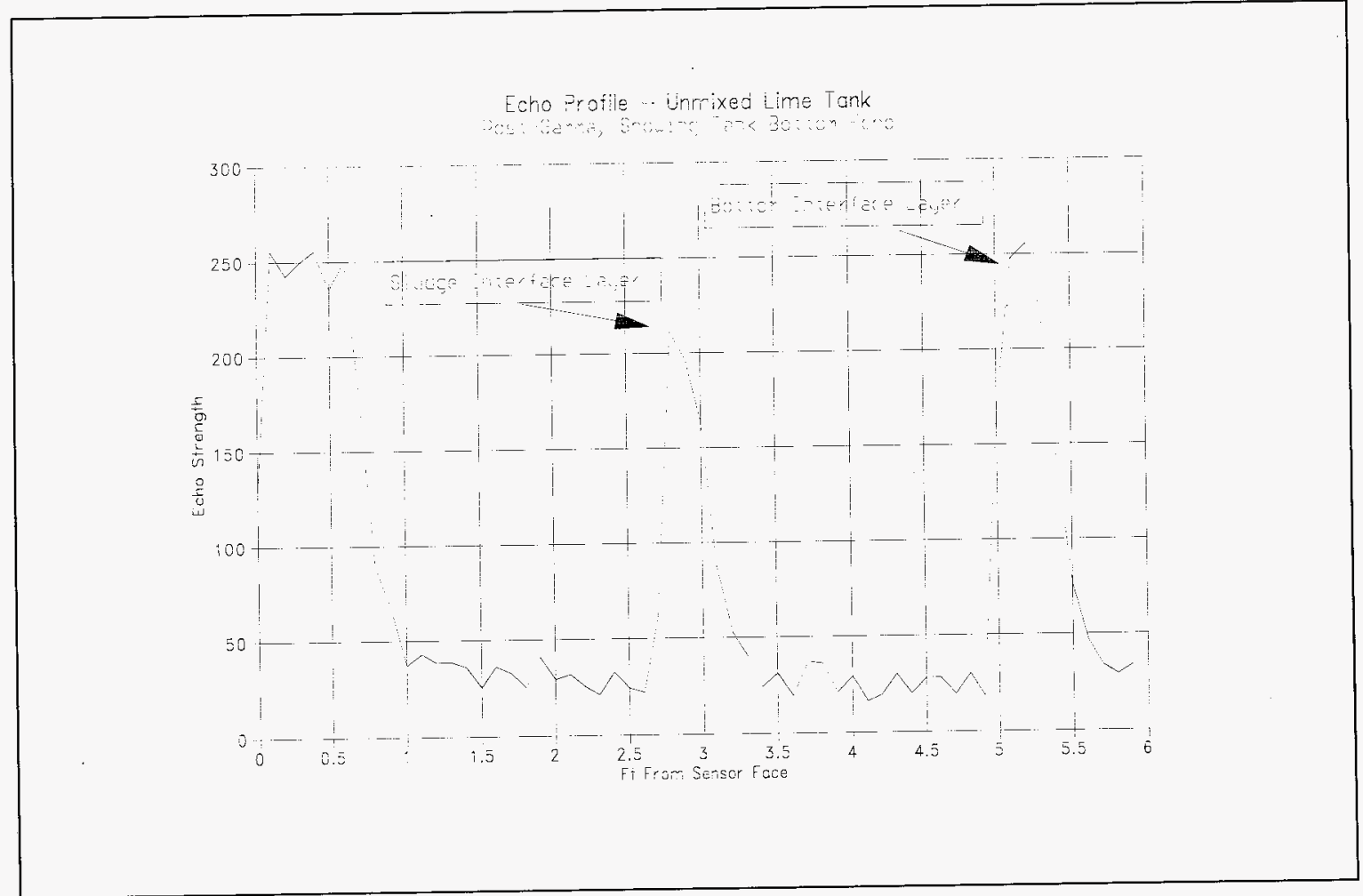

Figure 4 


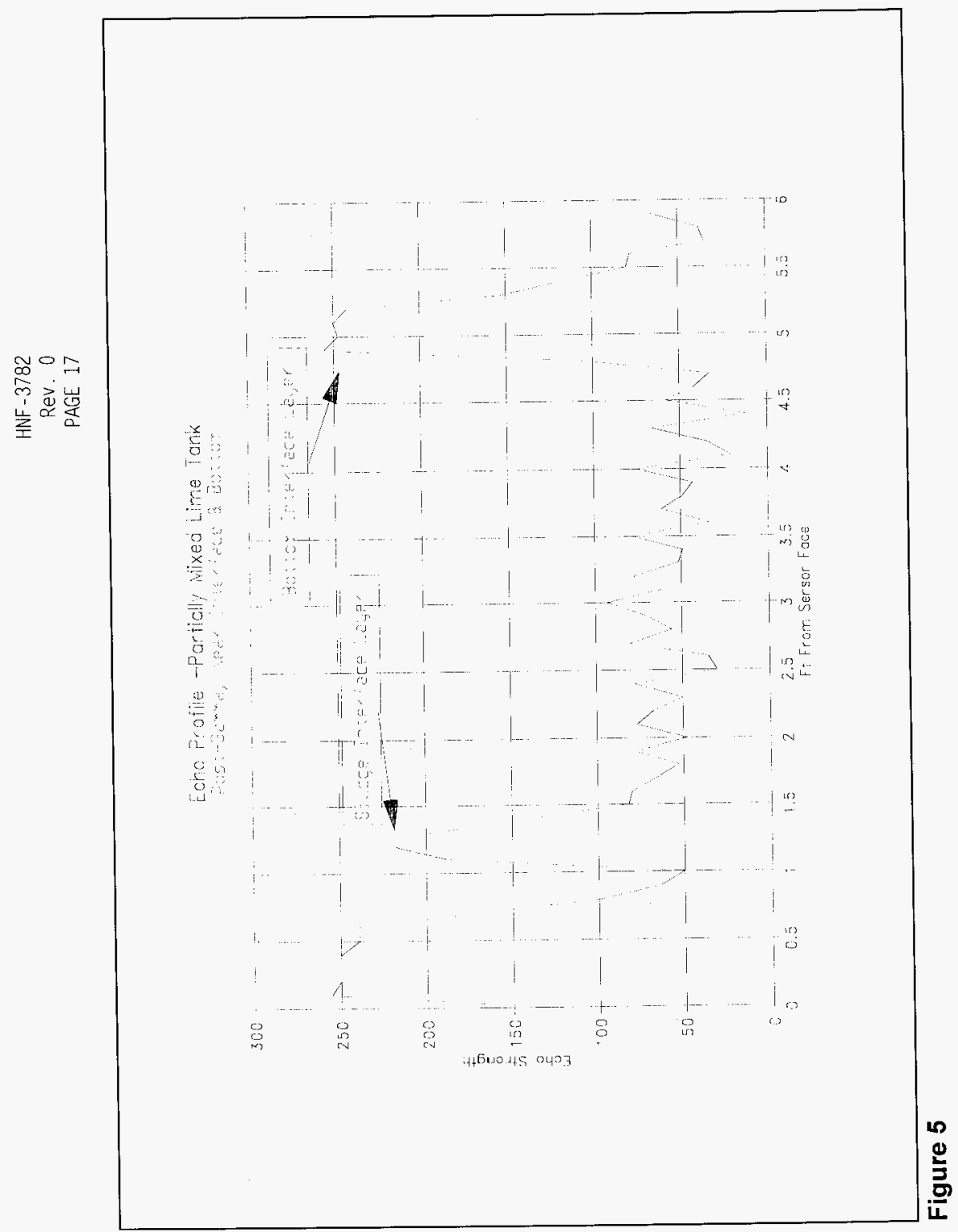




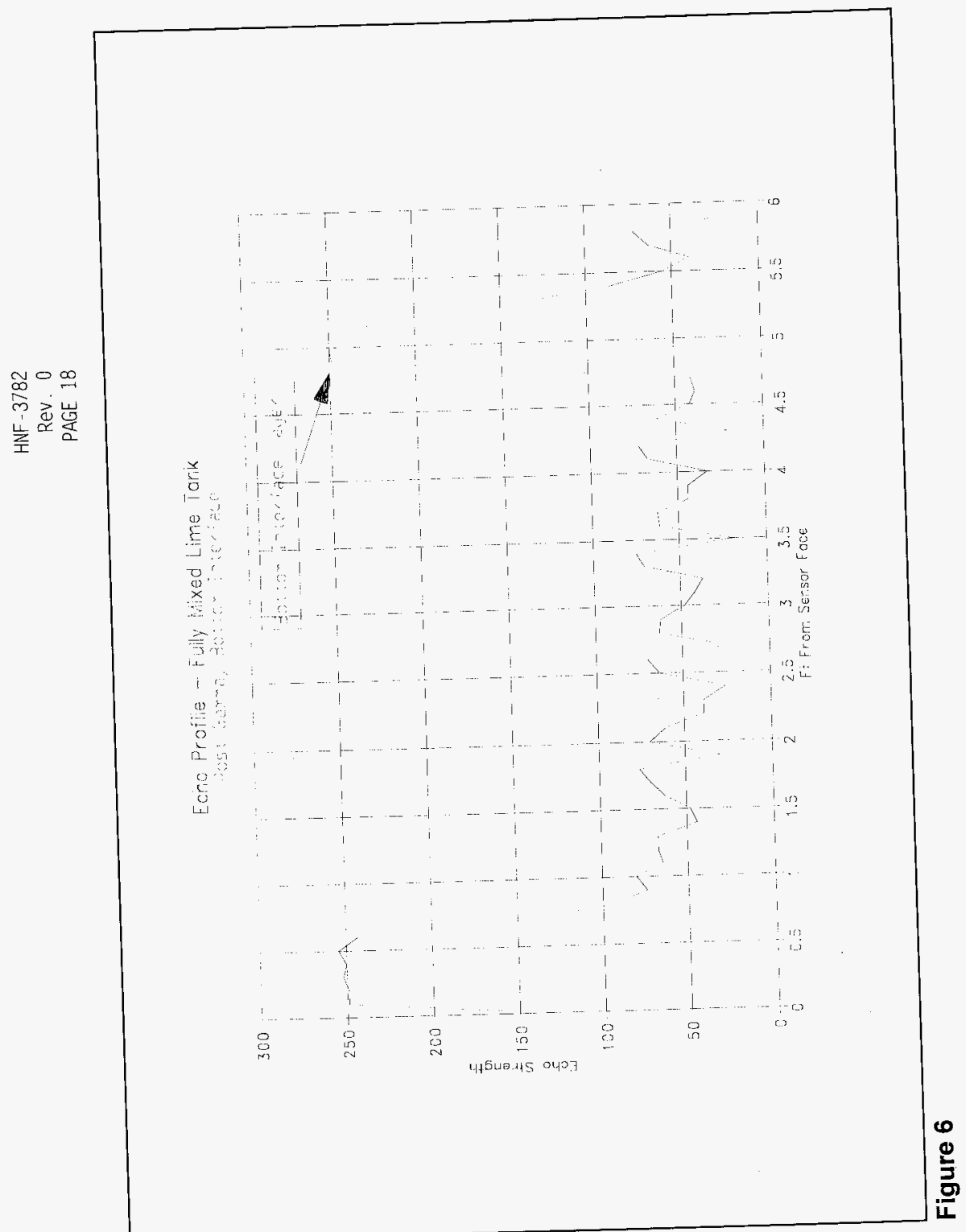




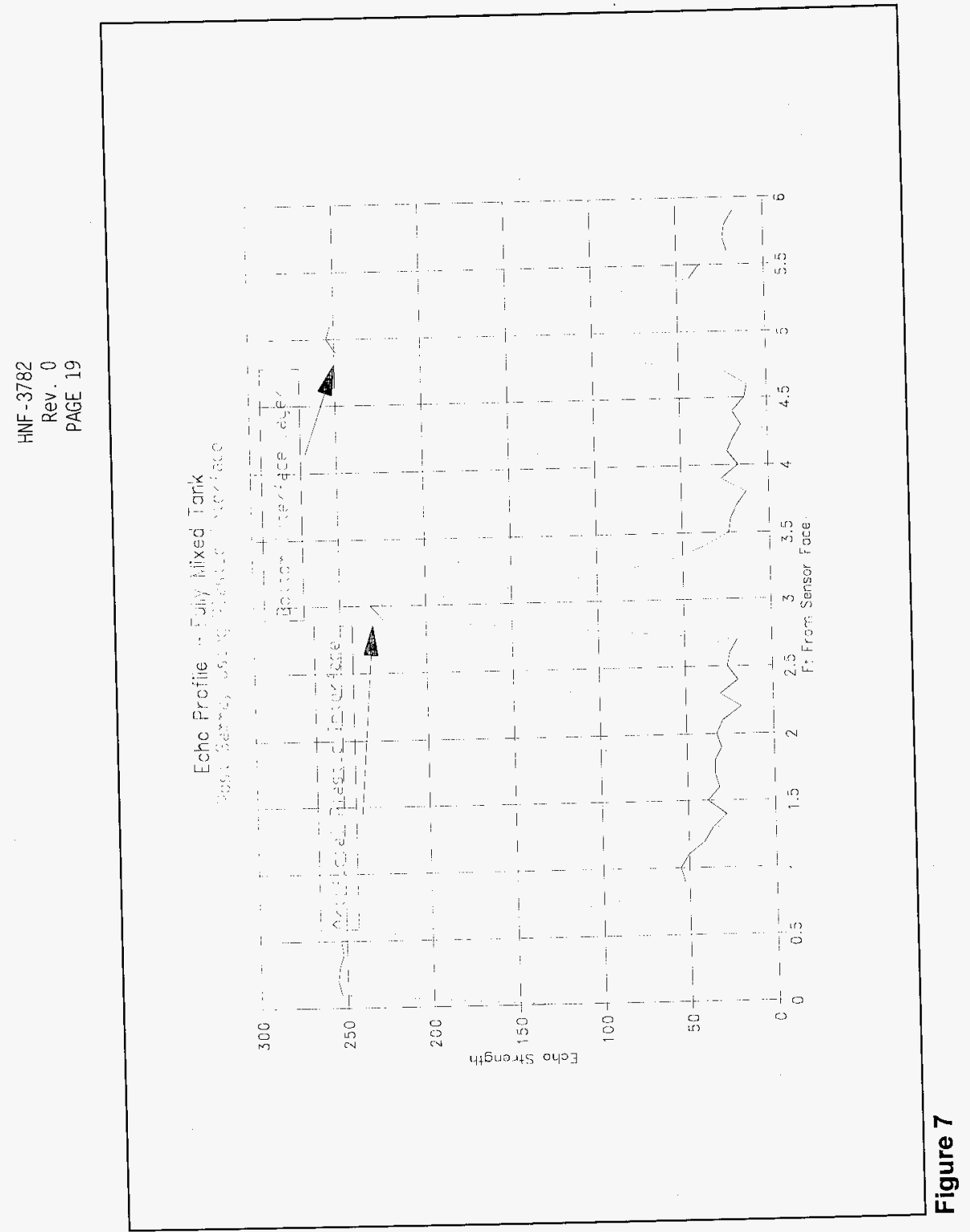


HNF -3782

Rev. 0

PAGE 20

APPENDIX B - GAMMA DOSE RATE INFORMATION

Figure 1 - Plot of Exposure Rate vs. Distance from Gamma source

Irradiation Data Sheet from Gamma Facility 


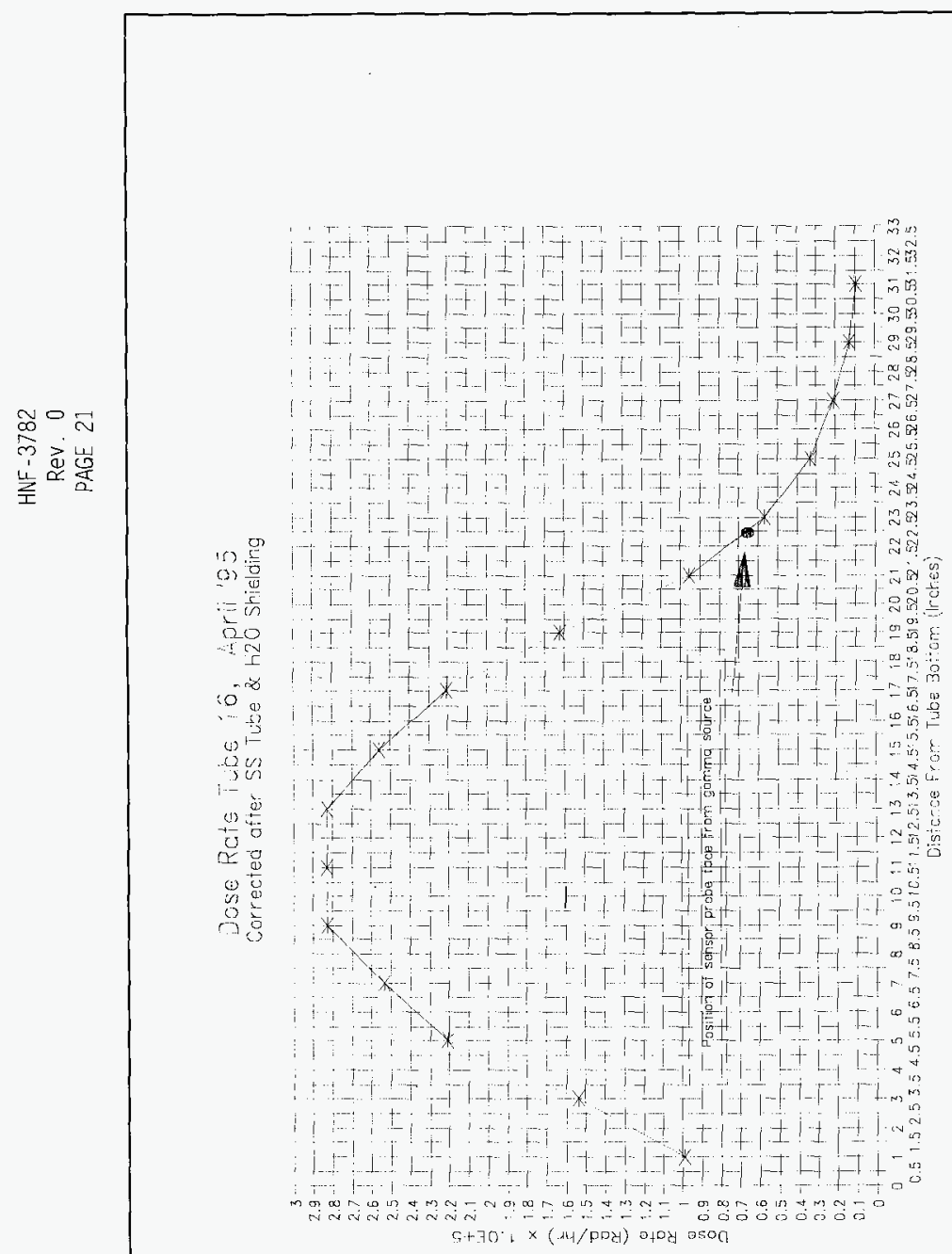




\section{Co-60 Gamma Irradiation Data Sheet}

Tube Number: $\quad 16$

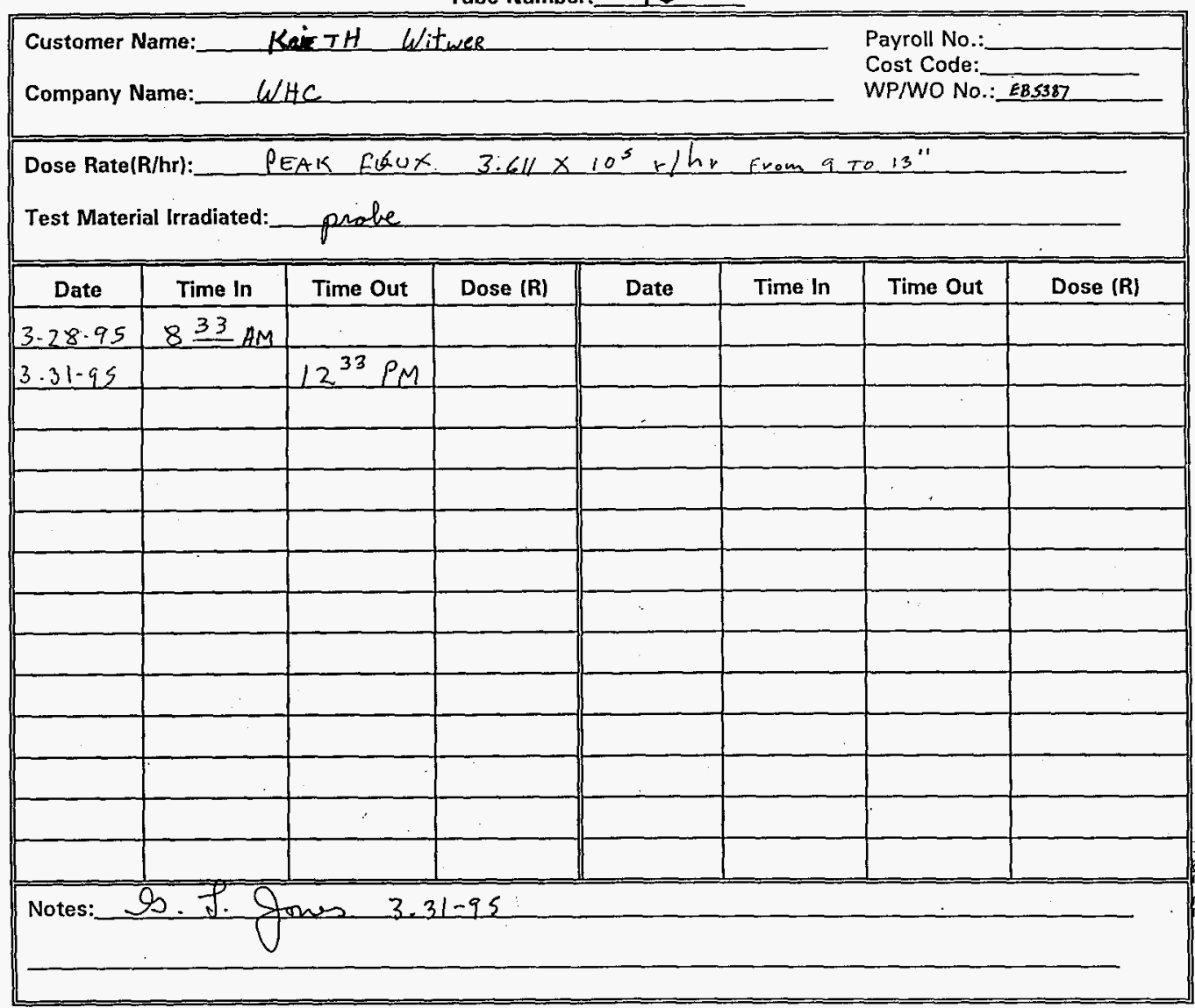


HNF-3782 Rev. 0 PAGE 23

APPENDIX C - IRON HYDROXIDE TANK TESTS 


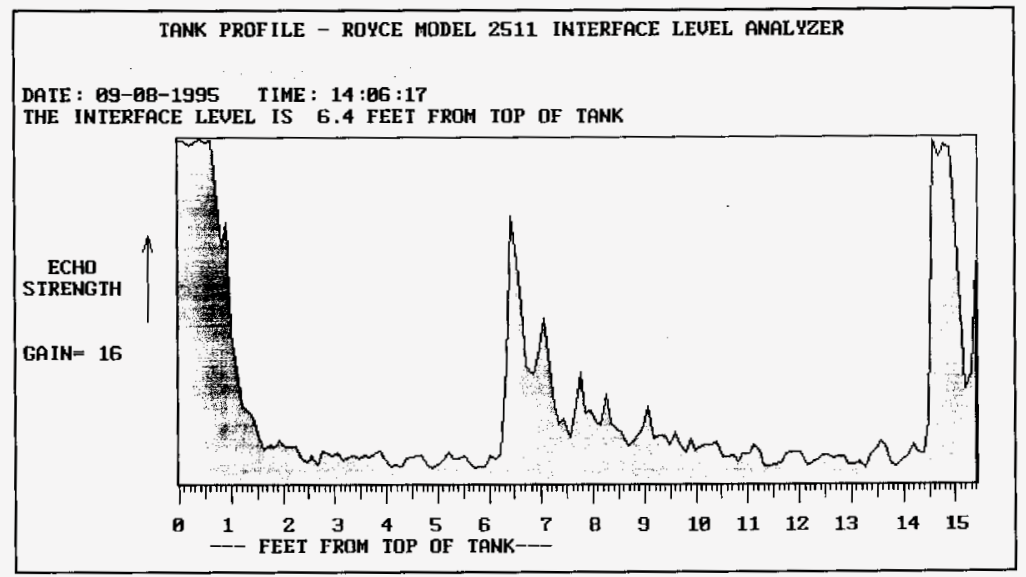

Graph 1

TANK PROFILE - ROYCE MODEL 2511 INIERFACE LEUEL ANALYZER

DATE : 69-68-1995 TIHE: $14: 13: 68$

THE INTERFACE LEUEL IS 6.0 FEET FROM TOP OF TANK

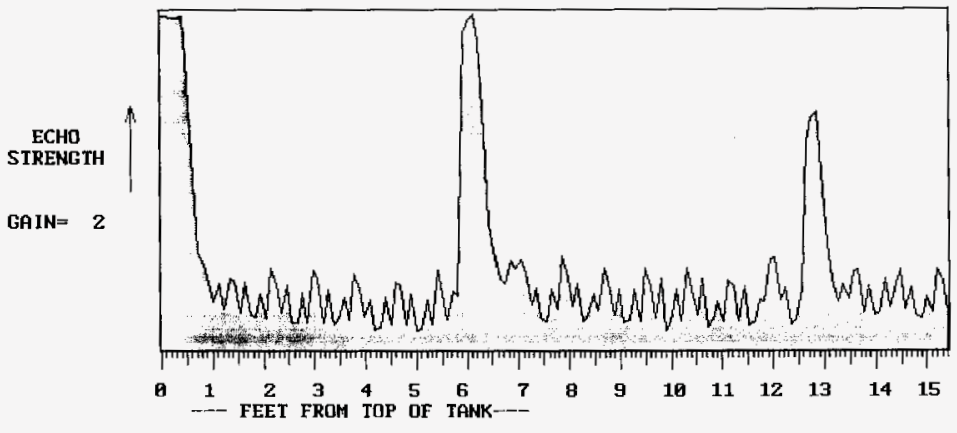

Graph 2 
TANK PROFILE - ROYCE MODEL 2511 INTERFACE LEUEL ANALYZER

DATE : 69-68-1995 TIME : $14: 18: 13$

THE INTERFACE LEUEL IS 5.3 FEET FROH TOP OF TANK

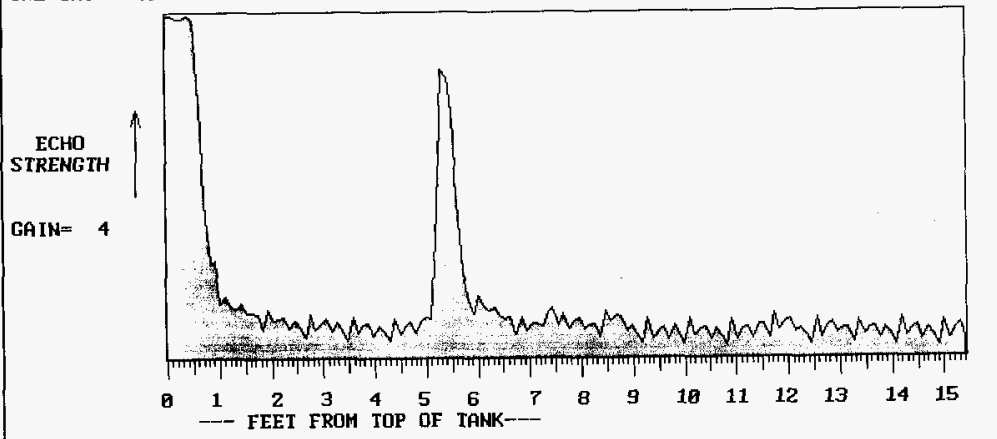

Graph 3

TANK PROF ILE - RDYCE MODEL 2511 INTERFACE LEUEL ANALYZER

DATE : 99-08-1995 T IME : $14: 25: 05$

THE INTERFACE LEUEL IS 4.1 FEET FROM TOP OF TANK

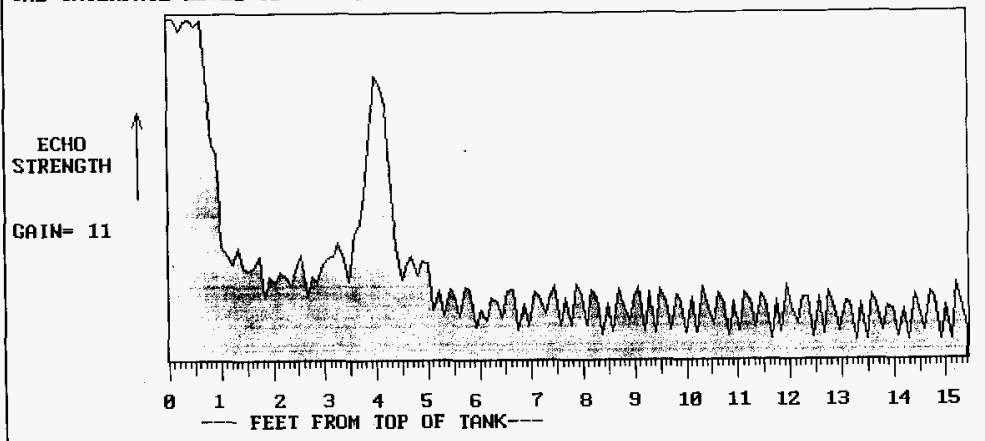

Graph 4 
TANK PROF ILE - ROYCE MODEL 2511 INTERFACE LEUEL ANALYZER

DATE : 09-08-1995 TIHE: $14: 35: 13$

THE INTERFACE LEUEL IS 2.2 FEET FROM TOP OF TANK

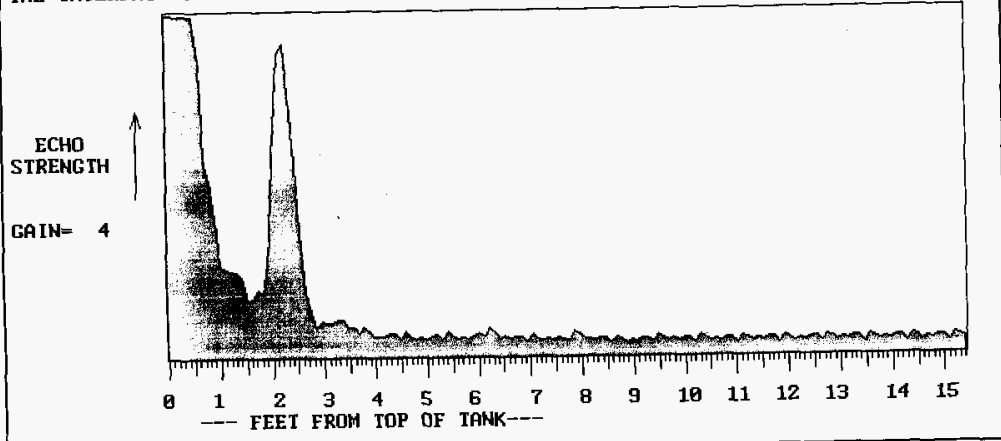

Graph 5

TANK PROFILE - ROYCE MODEL 2511 INTERFACE LEUEL ANALYZER

DATE : 09-08-1995 TIME : $15: 53: 30$

THE INTERFACE LEUEL IS 5.0 FEET FROM TOP OF TANK

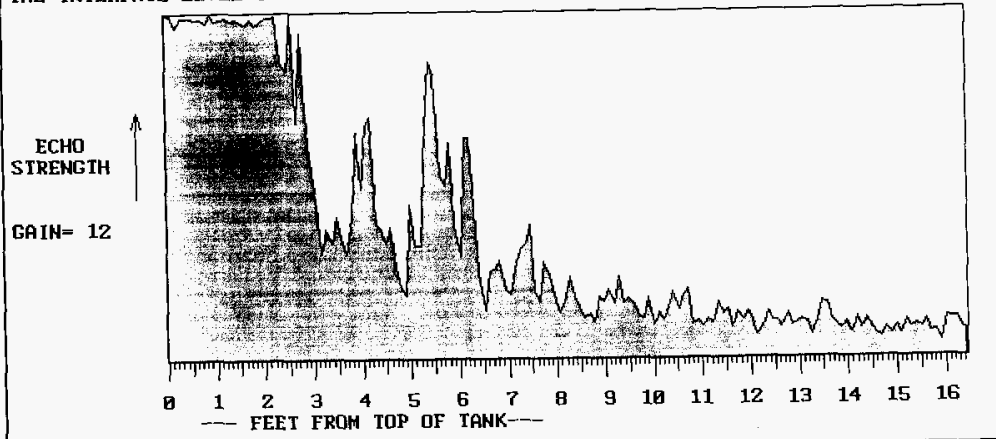

Graph 6 
DATE : 09-68-1995 T IME : $15: 56: 47$

THE INTERFACE LEUEL IS 5.9 FEET FROM TOP DF TANK

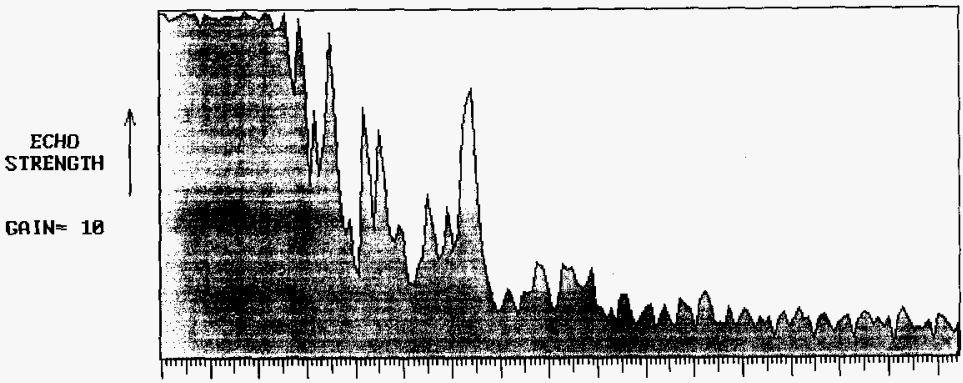

\begin{tabular}{lllllllllllllllll}
\hline & 1 & 2 & 3 & 4 & 5 & 6 & 7 & 8 & 9 & 10 & 11 & 12 & 13 & 14 & 15 & 16
\end{tabular}

Graph 7

TANK PROF ILE - ROYCE MDDEI, 2511 INTERFACE LEUEI ANALYZER

DATE : 09-68-1995 TIME: $16: 06: 39$

THE INTERFACE LEUEL IS 6.5 FEET FROM TOP DF TANK

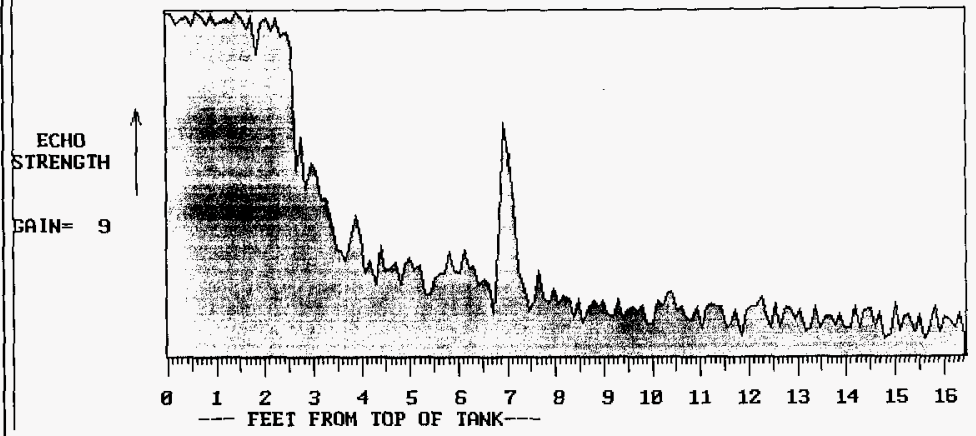

Graph 8 


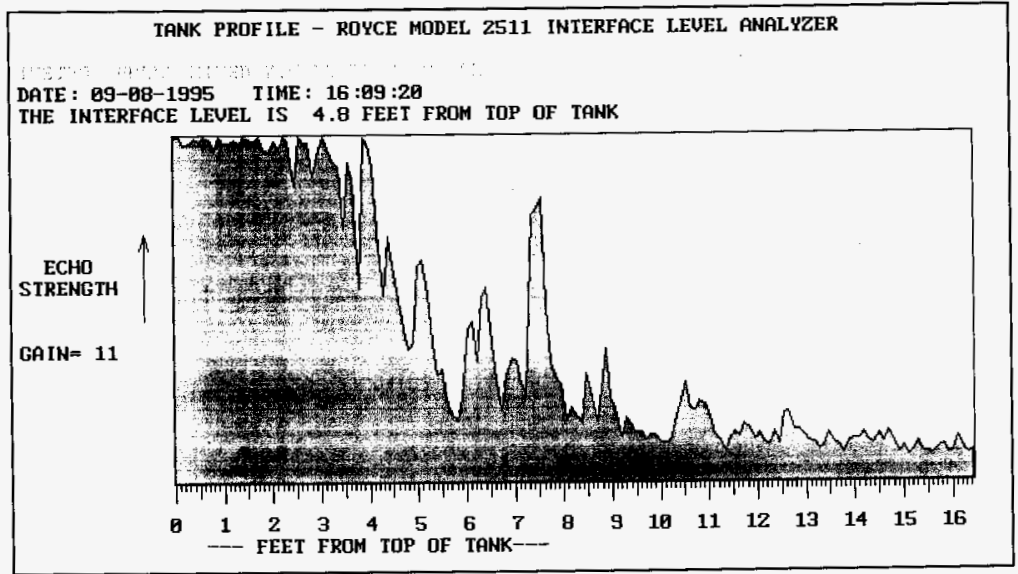

Graph 9

TANK PROFILE - ROYCE MODEL 2511 INTERFACE LEUEL ANALYZER

DATE : 09-08-1995 T IME : $16: 11: 52$

THE INTERFACE LEUEL IS 5.2 FEET FROM TOP OF TANIK

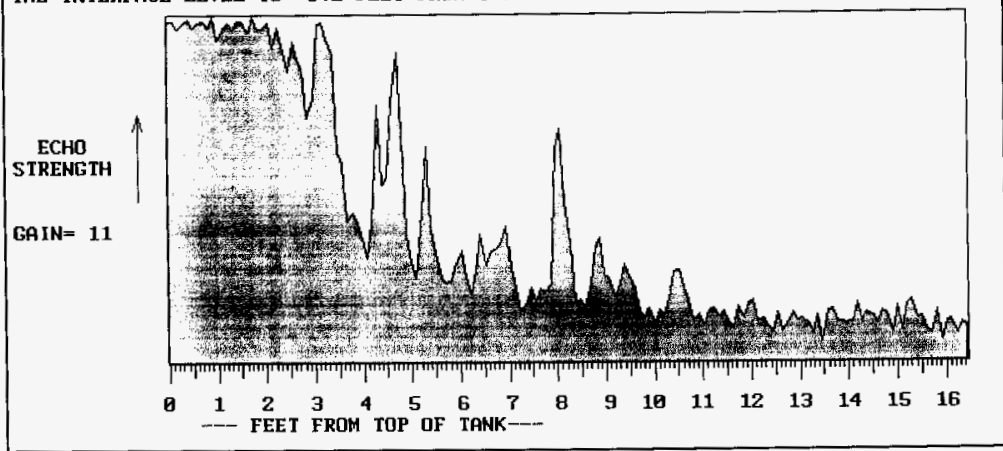

Graph 10 


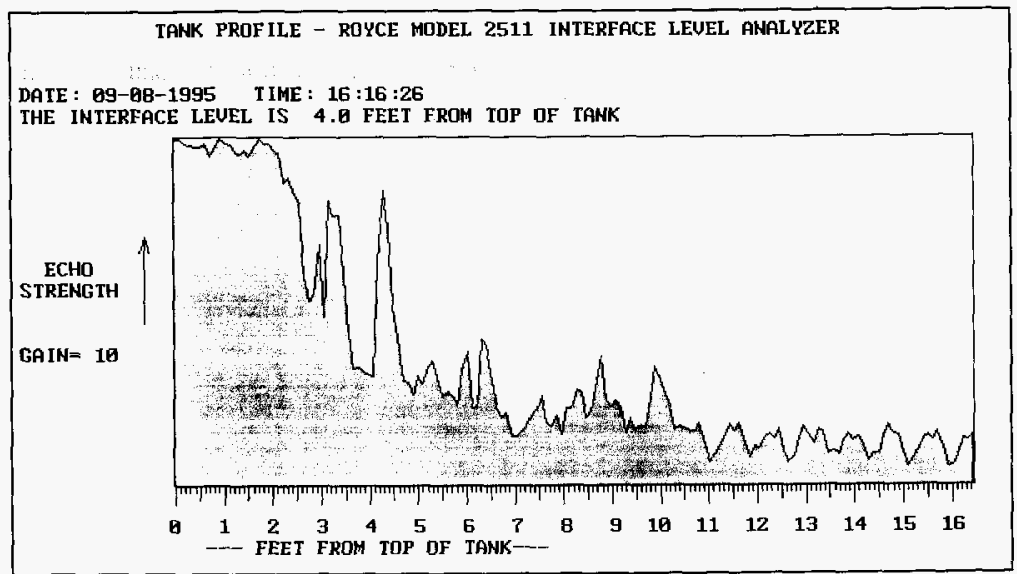

Graph 11

TANK PROF ILE - ROYCE MODEL 2511 INTERFACE LEUEL ANALYZER

DATE : 09-11-1995 TIME : $68: 55: 44$

THE INTERFACE LEUEL IS 7.3 FEET FROM TOP OF TANK

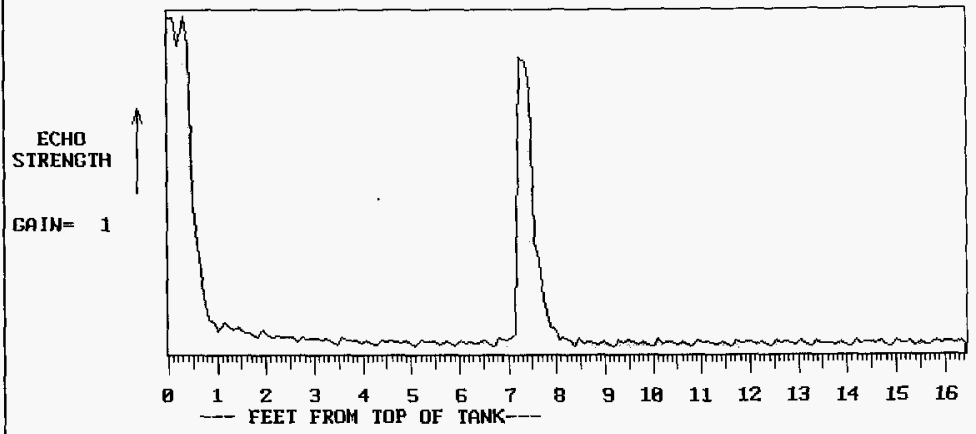

Graph 12 
TANK PROF ILE - ROYCE MUDEL 2511 INTERFACE LEUEL ANALYZER

DATE : 69-11-1995 TIME: $10: 25: 11$

THE INTERFACE LEUEL IS 5.8 FEET FROH TOP OF TANK

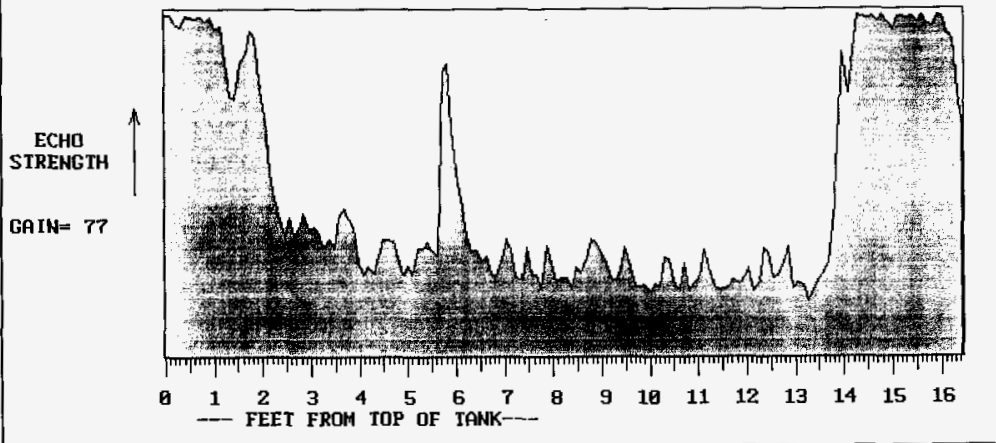

Graph 13

TANK PROFILE - ROYCE MODEL 2511 INTERFACE LEUEL ANALYZER

DATE : 09-11-1995 TIME: $18: 25: 56$

THE INTERFACE LEUEL IS 5.8 FEET FROM TOP OF TANK

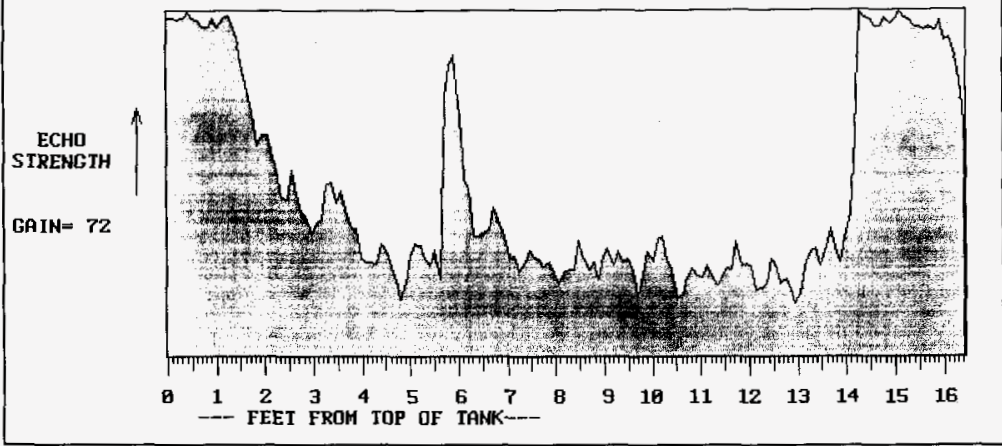

Graph 14 
TANK PROF ILE - ROYCE MODEL 2511 INTERFACE LEUEL ANALYZER

DATE : 09-11-1995 TIME : $10: 45: 06$

THE INTERFACE LEUEL IS 5.9 FEET FROM TOP OF TANK

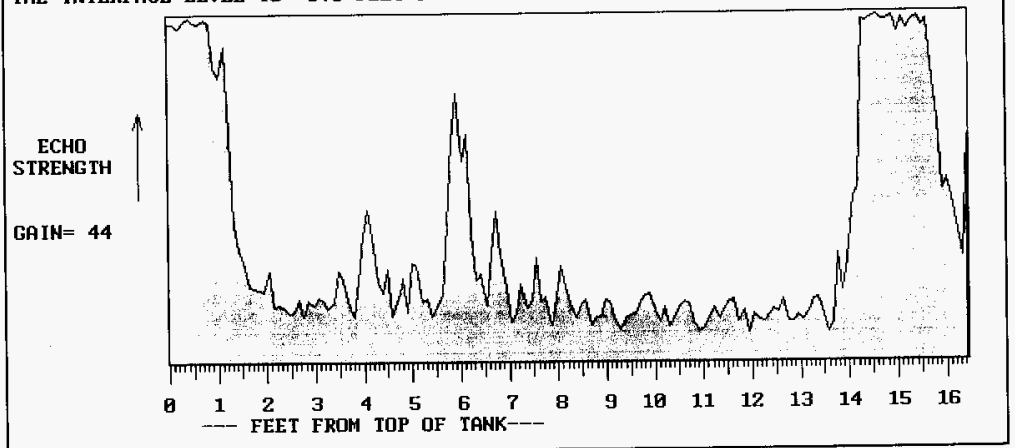

Graph 15

TANK PROFILE - ROYCE MODEL 2511 INTERFACE LEUEL ANALYZER

DATE : 99-11-1995 TIME : $10: 48: 14$

THE INTERFACE LEUEL IS 5.9 FEET FROM TOP OF TANK

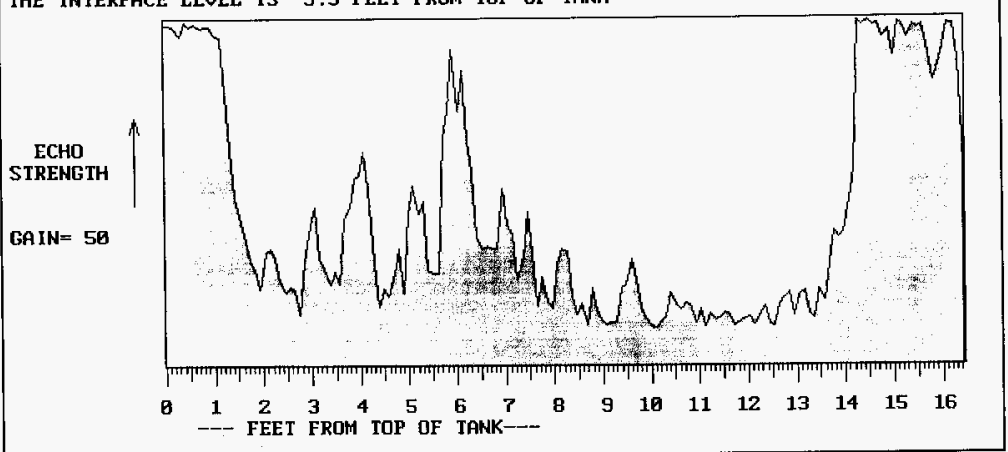

Graph 16 
DATE : 09-11-1995 T IME : $10: 38: 00$

THE INTERFACE LEUEL IS 4.1 FEET FROM TOP DF TANK

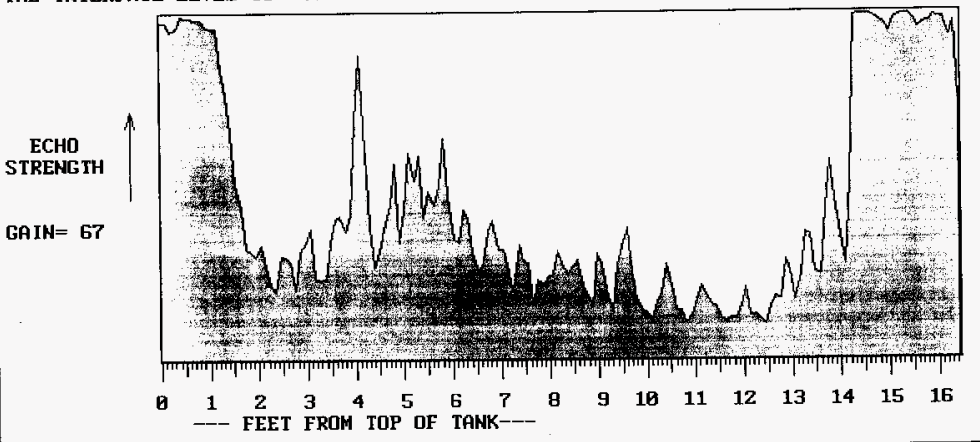

Graph 17

TANK PROF ILE - ROYCE MODEL 2511 INTERFACE LEUEL ANALYZER

DATE : 99-66-1995 TIME : $10: 02: 38$

THE INTERFACE LEUEL IS 2.6 FEET FROH TOP OF TANK

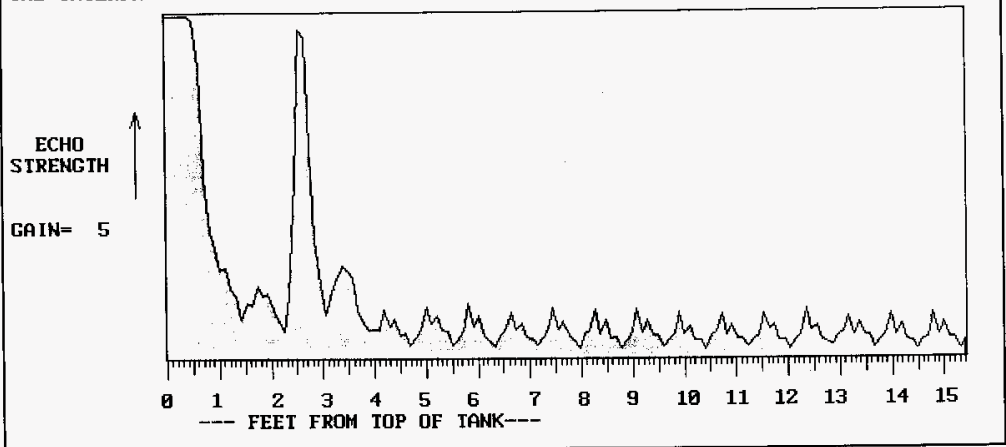

Graph 18 


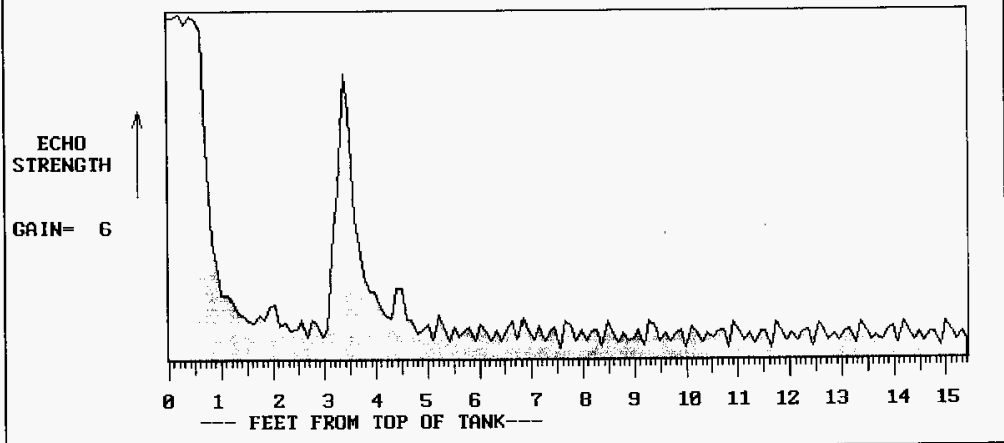

Graph 19

TANK PROF ILE - ROYCE HODEL 2511 INTERFACE LEUEL PNALYZER

DATE : 09-06-1995 TIME : $14: 30: 05$

THE INTERFACE LEUEL IS 3.7 FEET FROM TOP OF TANK

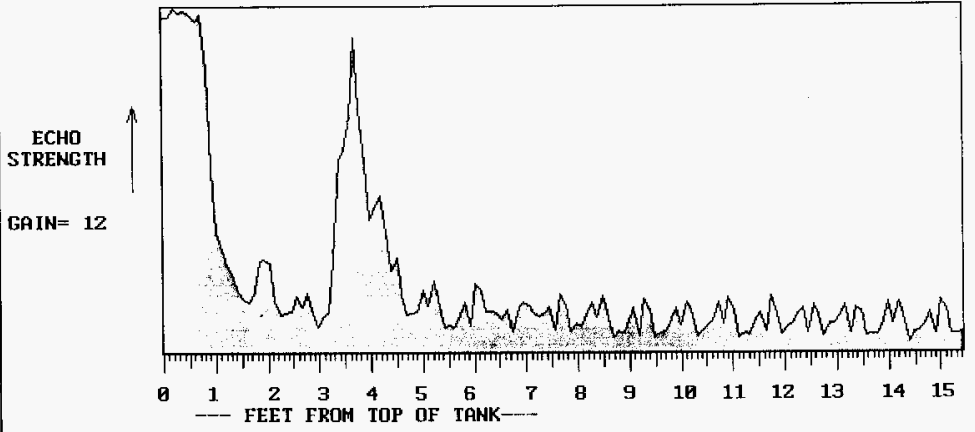


TANK PROF ILE - ROYCE MODEL 2511 INTERFACE LEUEL AMALYZER

DATE : 09-07-1995 TIME : $68: 33: 52$

THE INTERFACE LEUEL IS 4.2 FEET FROM TOP OF TANK

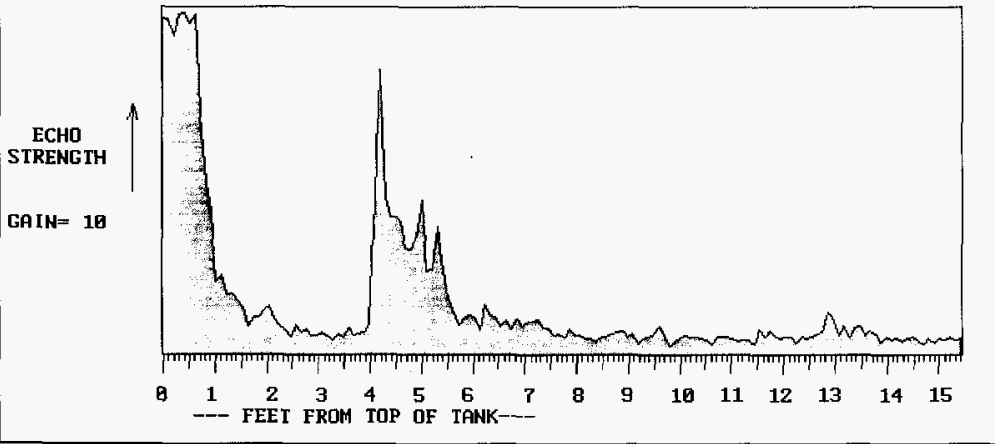

Graph 21

TANK PROF ILE - ROYCE HODEL 2511 INTERFACE LEUEL ANALYZER

DATE : 99-07-1995 T IME : $13: 04: 07$

THE INTERFACE LEUEL IS 6.5 FEET FROH TOP DF TANK

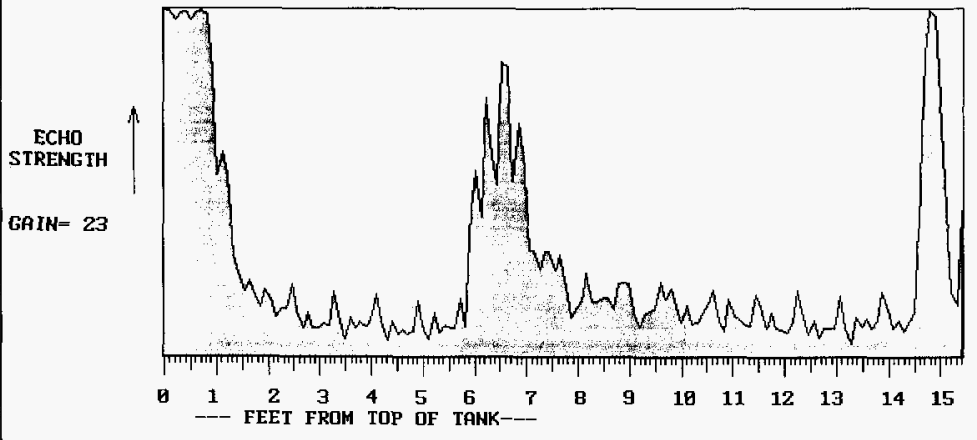

Graph 22 
TANK PROFILE - ROYCE MODEL 2511 INTERFACE LEUEL ANALYZER

DATE : 09-08-1995 TIME : $13: 57: 46$

THE INTERFACE LEUEL IS 6.6 FEET FROM TOP OF TANK

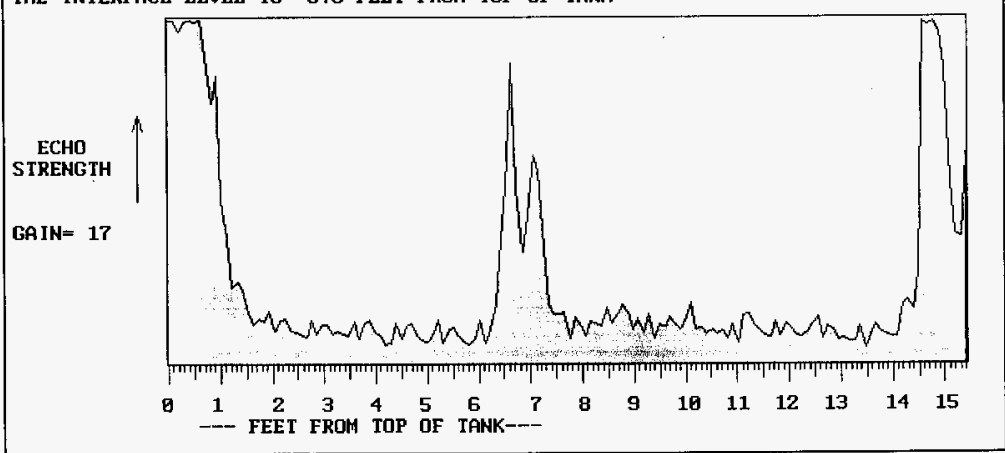

Graph 23 


\section{Settling Rate of Iron Hydroxide Simulant In $16 \mathrm{ft}$ Tall, $5 \mathrm{ft}$ Diameter Tank}

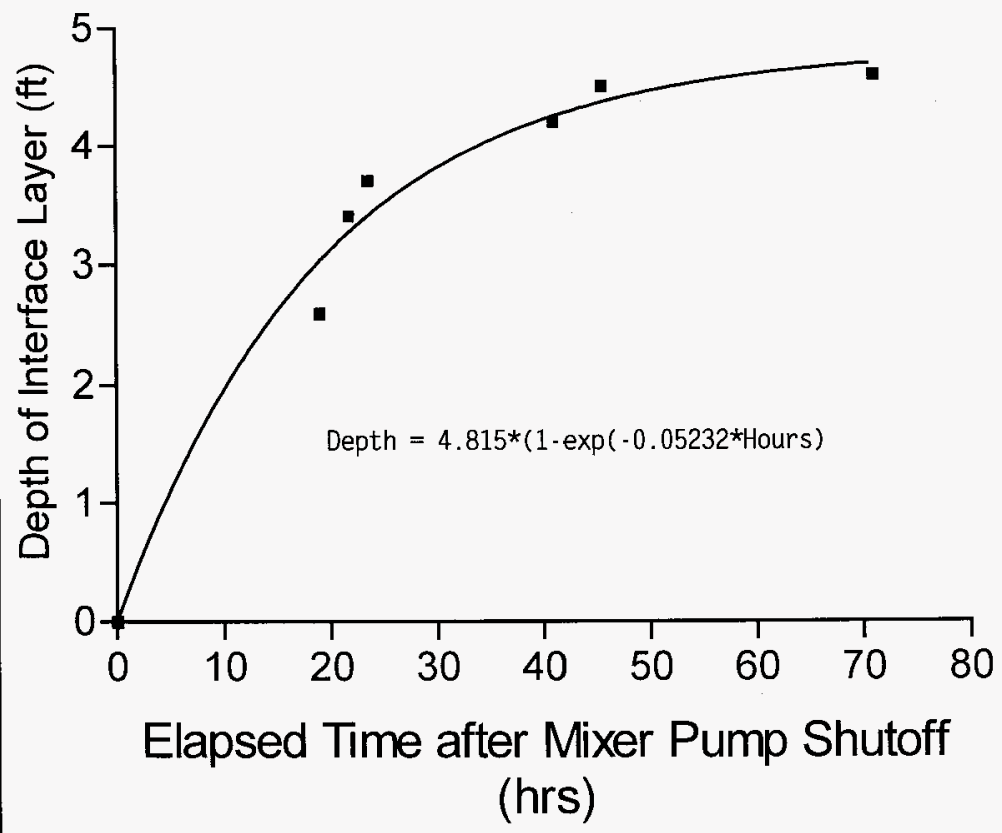

Graph 24 


\begin{tabular}{|c|c|c|c|c|c|}
\hline \multicolumn{6}{|c|}{ DISTRIBUTION SHEET } \\
\hline To & \multirow{2}{*}{\multicolumn{3}{|c|}{$\begin{array}{l}\text { From } \\
\text { Engineering Testing Laboratory } \\
8 \mathrm{C} 921\end{array}$}} & \multicolumn{2}{|l|}{ Page 1 of 1} \\
\hline Distribution & & & & \multicolumn{2}{|c|}{ Date $2 / 18 / 99$} \\
\hline \multicolumn{4}{|l|}{ Project Title/Work Order } & \multicolumn{2}{|c|}{ EDT No. 618466} \\
\hline Tests of the Royce U1tr & udge Interface & -evel Ana & yzer & \multicolumn{2}{|c|}{ ECN No, $\quad N / A$} \\
\hline Name & MSIN & $\begin{array}{l}\text { Text } \\
\text { With All } \\
\text { Attach. }\end{array}$ & Text Only & $\begin{array}{l}\text { Attach./ } \\
\text { Appendix } \\
\text { Only }\end{array}$ & $\begin{array}{c}\text { EDT/ECN } \\
\text { Only }\end{array}$ \\
\hline Alan Carlson & R3-73 & $x$ & & & \\
\hline Paul Certa & $R 3-73$ & $x$ & & & \\
\hline Ron Claghorn & R3-73 & $x$ & & & \\
\hline Tom Crawford & $\mathrm{R} 3-73$ & $x$ & & & \\
\hline John Galbraith & $\mathrm{R} 3-73$ & $x$ & & & \\
\hline Elie Girgis & $B 4-39$ & $x$ & & & \\
\hline Randy Kirkbride & R3-73 & $x$ & & & \\
\hline Graham Maclean & $B 4-45$ & $x$ & & & \\
\hline Ed Nordquist & $\mathrm{R} 3-73$ & $x$ & & & \\
\hline Ron Orme & R3-73 & $x$ & & & \\
\hline Brian Peters & $\mathrm{HI}-15$ & $x$ & & & \\
\hline Steve Romero & $B 2-67$ & $x$ & & & \\
\hline Tom Staehr & R3-74 & $x$ & & & \\
\hline Gary Stegan & $H 3-26$ & $x$ & & & \\
\hline Keith Witwer (2) & L6-13 & $x$ & & & \\
\hline Central Files & B1-07 & $x$ & & & \\
\hline D0E/RL Reading Room & $\mathrm{H} 2-53$ & $x$ & & & \\
\hline
\end{tabular}

